\title{
MEDIA CONVERGENCE STRATEGY OF PT. PIKIRAN RAKYAT
}

\author{
Ritzy Dika Riyadhiputra ${ }^{1}$, Freddy Yusanto ${ }^{2}$
}

Universitas Telkom

Naskah diterima tanggal 30 April 2019, direvisi tanggal 6 September 2019, disetujui tanggal 11 September 2019

\begin{abstract}
Abstrak. Salah satu perusahaan yang telah membuat konvergensi media adalah Pikiran Rakyat. Penelitian kualitatif dengan menggunakan metode studi kasus dilakukan melalui observasi dan wawancara mendalam dengan tiga informan dari Pikiran Rakyat. Penelitian ini bertujuan untuk menjelaskan secara mendalam tentang proses konvergensi, beberapa kendala dan evaluasi telah dilakukan oleh Pikiran Rakyat dalam menghadapi konvergensi media. Hasil penelitian ini menyimpulkan bahwa dari konvergensi teknologi, Pikiran Rakyat telah mengembangkan inovasi baru seperti aplikasi MyPakRakyat, PRTV, dan situs web Pikiran Rakyat dan juga bekerja sama dengan UKM (Usaha Kecil dan Menengah), klub pemuda, vloggers, dan blogger lokal untuk memperkaya konten digital mereka. Namun, perkembangan teknologinya masih terkendala oleh kemampuan sumber daya manusia dalam memahami teknologi digital dan karakteristiknya. Solusi yang dibuat adalah Pikiran Rakyat terus mencari karyawan baru dengan usia yang lebih muda, memilah beberapa karyawan yang tidak produktif dan memperbarui perkembangan teknologi media digital serta membangun budaya kerja baru yang disesuaikan dengan karakteristik media digital.
\end{abstract}

\section{Kata Kunci : Konvergensi Media, Pikiran Rakyat, Media Online}

Abstract. One of the companies that has made media convergence is Pikiran Rakyat. Qualitative research using case study method was carried out through observation and in-depth interviews with three informants from Pikiran Rakyat. This study aims to explain in depth about process of convergence, some obstacles and evaluations have been made by Pikiran Rakyat in facing media convergence. The results of this study conclude that from technological convergence, Pikiran Rakyat has developed new innovations such as MyPikiranRakyat application, PRTV, and Pikiran Rakyat website and also cooperate with SMEs (Small and Medium Enterprises), youth clubs, vloggers, and local bloggers to enrich their digital content. However, its technology development is still constrained by the ability of human resources in understanding digital technology and its characteristics. The solution made is Pikiran Rakyat continues for seeking new employees with younger age, sort some unproductive employees, keep updating the development of digital media technology and build a new working culture which adjusted to the characteristics of digital media.

Keywords : Media Convergence, Pikiran Rakyat, Online Media 


\section{INTRODUCTION}

The development of information and communication technology today makes patterns of human behavior can change, one of which is in meeting the need for information. Digital media is currently one of the mediums for obtaining information, entertainment and news. As reported by one article entitled "Print Media Able to Defend Its Position" from the survey results of the Nielsen Consumer and Media View agency stated that up to the third quarter of 2017 the print media did not lose their readers, but their readers are now switching platforms to digital media (Mila , 2017). Thus, in this digital age, the role of technology becomes a great power that can change the culture of people to get information. This digital technology has introduced and redefined content as well as the role of journalism. This new type of media has become a tool for journalists to gather information. They benefit journalism in several ways. When comparing new and traditional media (newspapers, television and radio), it is clear that the difference between the two has become blurred. They have undergone convergence through an unprecedented webification process, thereby creating an unprecedented form of journalism (Chao-Chen, 2013).

History of the Pikiran Rakyat Neswpaper is one of the few regional newspapers that is able to stem the circulation of newspapers that come from Jakarta as well as the Jawa Pos Daily in East Java and Suara Merdeka in Central Java, the Pikiran Rakyat Newspaper fluttering in its area, West Java. Since its inception, Pikiran Rakyat Newspaper daily declared itself as a regional newspaper. Therefore, in carrying out their duties both related to collection, broadcasting, as well as statements and opinion gathering, this daily has its own style that is different from the national periodic daily.

The policy refers to the target audience consisting of the people of West Java. The idealism that underlies the existence of the Pikiran Rakyat Newspaper can be read clearly from its motto "From the People for the People by the People". That makes this daily achievement as a public servant who tries to orient all his work to the interests of the community. Another motto that underlies the Pikiran Rakyat Newspaper is "Independent". This motto means the Pikiran Rakyat Newspaper as a news presenter trying to maintain its presence in the sense of not opening opportunities to be influenced by other parties.

The Pikiran Rakyat Newspaper daily has a fairly unique developmental history, because this daily status was originally independent, then became an official organization of the Indonesian Army, and eventually became an Independent Newspaper until now. The Pikiran Rakyat Newspaper since its inception declared itself as a regional newspaper. Thus in carrying out its duties, both in the collection, broadcasting and statement and expression of opinions must be in accordance with the characteristics of Pikiran Rakyat Newspaper. Pikiran Rakyat Newspaper prioritizes news about events that occur in West Java, without prejudice at all to news about problems and events national, international, or other regional regional. Beside that Pikiran Rakyat Newspaper prioritizes editorials and other writings on problems or events concerning the regions and people of West Java without putting aside international, regional or domestic events. It also participated in the activities of the government and the people of West Java, another ideal which wanted to be realized by Pikiran Rakyat Newspaper as an exemplary newspaper, both editorial and management.

Based on research carried out by AMIC (Asian Mass Communication Research and Information Center) in 1984, Pikiran Rakyat Newspaper was placed as one of "The Five Successful Asian Community Newspapers" or Five Successful Regional Newspapers in Asia. In addition, Pikiran Rakyat Newspaper succeeded in placing itself in the top 10 newspaper groups in Indonesia based on its circulation. Meanwhile, based on data available in the circulation section, 
the comparison in 1972, the Pikiran Rakyat Newspaper was able to attend with a circulation of 33,000 copies every day, that number continued to grow to 135,000 copies every day in 1982 , and at that time it continued to grow with a 180,000 circulation -200,000 copies every day.

Pikiran Rakyat has developed its digital media since 1996. It is based on the consideration that the more expensive the price of paper, resulting in higher production costs, while newspaper readership continues to decline, due to the newspaper's readers have been turning to online media. The decline of readers has an impact on the decline in newspaper circulation, which has affected fewer manufacturers advertise their products Pikiran Rakyat newspaper. Executive Director of United Company Press (SPS) Indonesia, Asmono Wikan, print media states collapsed because they could no longer face the macroeconomic situation. This causes the printing material to be expensive, such as paper and ink and coupled with the imbalance of incoming advertising (Prihatin, 2015).

As reported by a news portal merdeka.com in one of his articles, published in November 2015, states that there is one newspaper that is no longer exist, that is Jakarta Globe (Intan, 2015). This newspaper is no longer able to maintain the existing print media. Jakarta Globe now turned into a complete digital media.

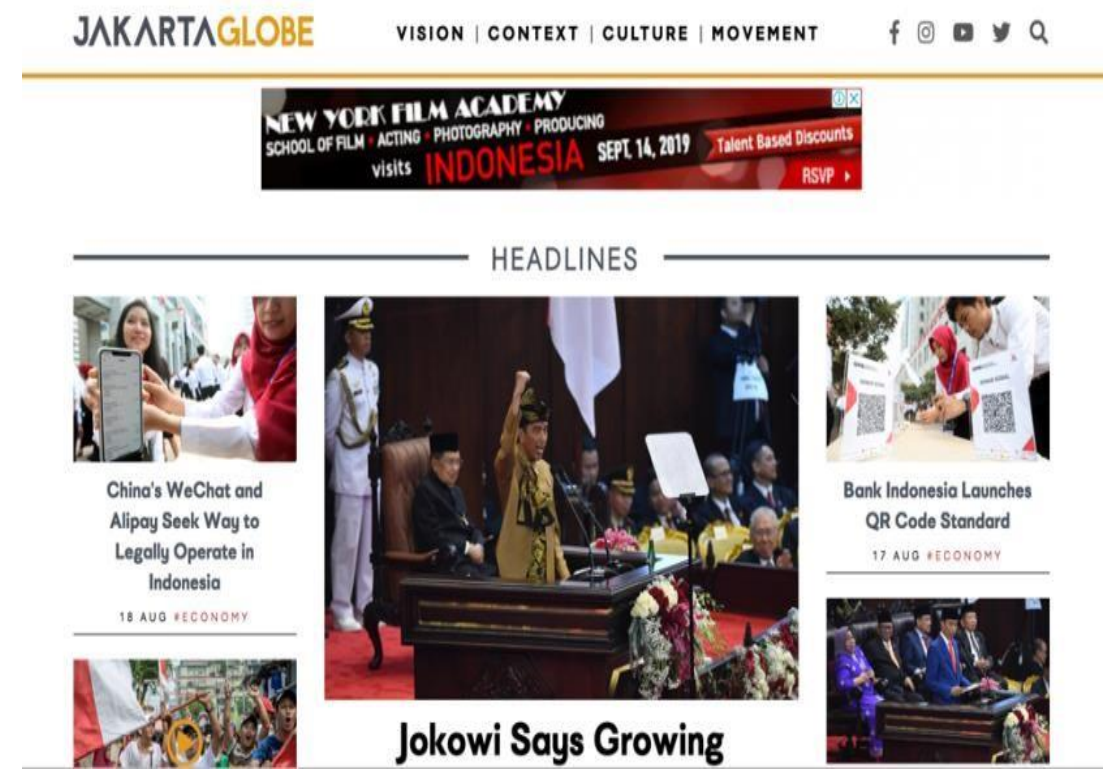

Source: https://jakartaglobe.id//

Figure 1. Jakartaglobe Website

It is an evidence of information and communication technologies development that are becoming a real challenge for print media companies in the era of digitalization today. The development of information and communication technology eventually influenced the mass media to implement media convergence through new media such as websites, streaming access, and others. In addition, media convergence also has to do with the media industry, where media convergence is currently a factor in the development of the media, so that the media can now be present in various types of media platforms (Haryanto, 2014). Media convergence ideally according to Russell Neuman (1991) in Ibrahim \& Akhmad, states that the development of this technology results changes or continuity, new media tend to be inexpensive and also easy to obtain by the public, new media changes the audience's perception about distance, new technology can 
increase the speed of communication process, new technology can also increase more communication channels, there is more control for users, and there are many interactions of previously separate forms of communication (Idi Subandy Ibrahim \& Akhmad, 2014). The main innovation in the field of technology is the media ability to a virtual transition from analog to digital technology. The second innovation is to become an important point of convergence for the spread of the internet that can connect computers in a network. All information can be disseminated anytime and anywhere via internet. The identical key to media convergence is digitalization, all forms of information or data can be changed from analog to digital (KPI, 2013). The presence of digital information technology, resulting in differences in process, the delivery, the user's behavior changes even the media itself. But as a medium that serves as a medium of information, entertainment and education, conventional media and new media still have similarities, particularly in terms of content quality (Gumelar, 2011).

Survival phenomenon as print media companies in the digital age has been conducted by Pikiran Rakyat Daily Thoughts. According to Yusuf Wijanarko, Pikiran Rakyat Content Manager, stated that Pikiran Rakyat still maintains the existence of its company while today's media development has been rapid. Bambang Triadji as the Head of Information Technology of Pikiran Rakyat, said that Pikiran Rakyat has been using a digital media platform since 1996 with the aim of providing easy access information, especially in West Java region. Currently Pikiran Rakyat is engaged in print media (Pikiran Rakyat daily) and digital media (Pikiran-rakyat.com).
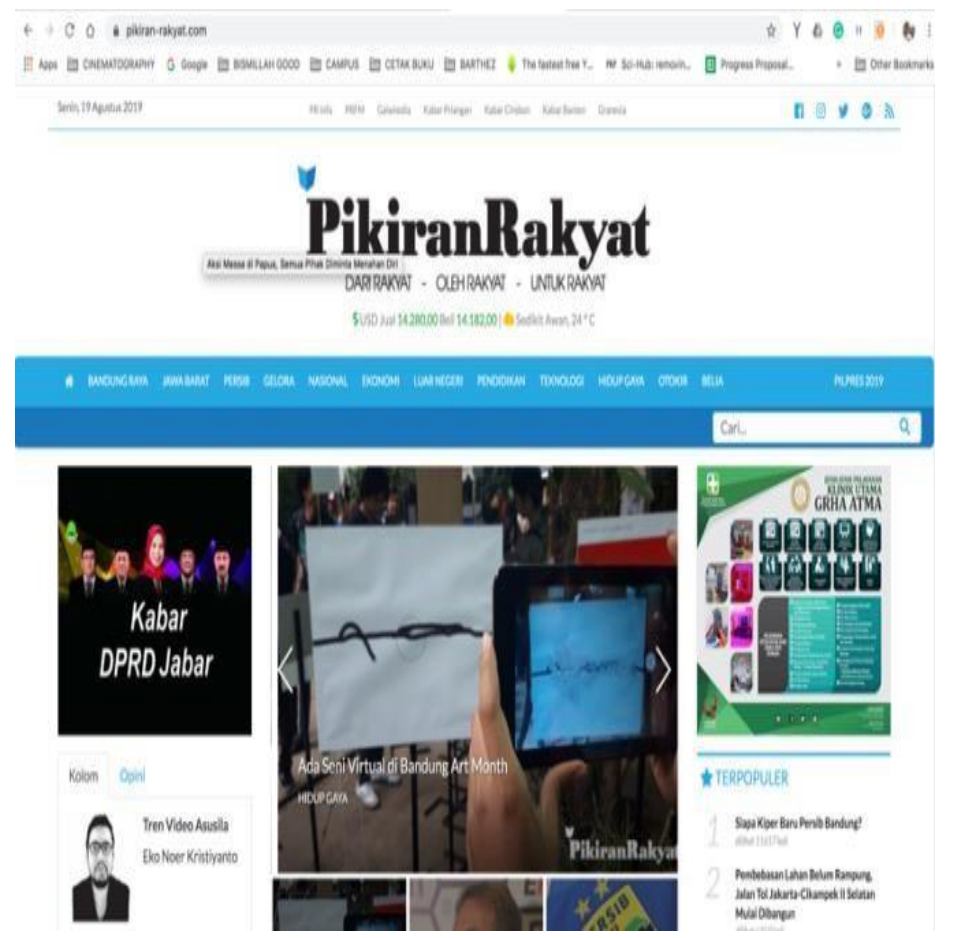

Source: https://www.pikiran-rakyat.com

Figure 1. Pikiran-rakyat.com Website 
This qualitative research with case study approach aims to clarify and explain the media convergence strategy of Pikiran Rakyat in maintaining the existence of its company. Regarding media convergence, Khomsahrial Romli said that the convergence of media covers five major dimensions: technological convergence, multimedia content, ownership, collaboration and coordination. Those five dimension can be optimized as the elements of preparation in media convergence strategy for companies engaged in media. This research lasted for five months, starting from observing the phenomenon happening in Pikiran Rakyat to find out the strategy of maintaining the company existence, then thinking about the media convergence strategy used, considering the process, constraints, and evaluating the strategy. This research was conducted in two Pikiran Rakyat Offices, first at Jalan Asia Afrika, No. 77, Braga, Sumur Bandung, and the second at Ruko Plaza Complex, Jalan Peta, Bandung City, West Java.

\section{RESULT AND DISCUSSION}

Convergence occurs not only because of technological changes, but also cultural changes that occur where media users are increasingly encouraged to use media platforms to get new information and try to connect media content that was previously spread. Media convergence also has dimensions to support the process of convergence.

Table 1

Dimensions in Supporting Convergence Process

\begin{tabular}{l|l}
\hline Technological Convergence & $\begin{array}{l}\text { Website www.pikiran- } \\
\text { rakyat.com }\end{array}$ \\
\cline { 2 - 2 } & PRTV YouTube channel \\
\cline { 2 - 2 } Application MyPikiranRakyat \\
\hline \multirow{2}{*}{ Multimedia Content } & $\begin{array}{l}\text { Big folder contained all } \\
\text { information }\end{array}$ \\
\cline { 2 - 2 } & $\begin{array}{l}\text { Cooperates with several outside } \\
\text { parties such as SMEs, Youth } \\
\text { Organization, local vloggers } \\
\text { bloggers }\end{array}$ \\
\hline Ownership & Joint ownership \\
\hline Obstacles & $\begin{array}{l}\text { Adaption to technological } \\
\text { developments }\end{array}$ \\
\cline { 2 - 2 } & Technological adjustment \\
\hline Evaluation & $\begin{array}{l}\text { Technological infrastructure } \\
\text { regeneration }\end{array}$ \\
\cline { 2 - 2 } & Obtaining human resource \\
\hline
\end{tabular}

The process of convergence is merging or transforming print media with digital media. Pikiran Rakyat has made technological convergence by creating a website www.pikiran-rakyat.com and an android-based application called MyPikiranRakyat. This convergence is expected to help 
facilitate people in obtaining information and as part of a strategy to survive in digital age.

Pikiran Rakyat is also developing its latest innovation, PRTV YouTube channel, at the end of 2018. Positive impact arised is Pikiran Rakyat has a new platform so that the company can keep abreast of technological developments in current digital era. The negative impact is; HR applies a gradual selection less productive employee or the ones who difficult to adjust themselves with development of existing technology.

Multimedia content displays a variety of content formats in one media. In managing print and digital media content, Pikiran Rakyat runs a different strategy. News editors in digital media are called uploaders, whereas in print media the workflow of editors is limited to scripts that are ready to print.

This difference in workflow must be learned by each editor in the digital media platform. Another difference is the time to manage content. Print media takes more time than digital media management. Currently Pikiran Rakyat has been developing in multimedia content management. The latest developments made are by making large baskets. The basket means here is a big folder contained all information, in this large basket journalists are required to increase their productivity in processing the data.

In addition, Pikiran Rakyat also cooperates with several outside parties such as SMEs, Youth Organization, as well as with local vloggers and bloggers. This method is conducted by Pikiran Rakyat to enrich the content in its media.

Ownership in the convergence dimension considered as the most important dimension. Ownership in a company is a person who holds full control of the company. PT. Pikiran Rakyat is one of the media companies held by 28 people. These 28 people hold many subsidiary companies of Pikiran Rakyat, such as Galamedia, Kabar Cirebon, and many more. The existence of joint ownership might have negative impacts such as difficulty of making decisions, so that this can hamper the development of Pikiran Rakyat media convergence.

The first obstacle is that there must be technological adjustments to technology that has long been built by Pikiran Rakyat since the 2000s. The second obstacle is difficulties faced by some human resources to adapt to technological developments. The average age of HR here is above 45 years. The third obstacle is mindset and work ethic felt directly by Pikiran Rakyat editorial staff. Constraints on changing work methods and different work cultures in print and digital media, may not necessarily be followed by all employees. Change positions for the sake of efficiency and adjustment to the needs of the position in digital media, it is often very difficult to conduct; since the adjustment process is not easy for a staff who is transferred from one position to another. One of the reasons is due to age.

The effect of shock culture that occurs at the beginning of a change in position is felt by the employees. Significant changes in work culture and work methods cannot be followed by all employees. Previously, the editorial staff had never worked with computers for more than 8 hours a day, because they were accustomed to interviews in the field, then transcribed the results of interviews. So that the time needed is in front of a computer screen no more than 2 hours. While now, they must monitor information online at least 8 hours in one day. Then the editorial staff must read and perform editing text scripts sent from field journalists. It was very difficult at the beginning of the change, but there are some employees who are able to adapt and finally feel comfortable working on a digital platform.

Evaluation conducted by Pikiran Rakyat is to replace the existing technological infrastructure, then carry out the regeneration in a structured, to obtain the composition of human resources who can contribute the maximum. Based on the experience so far, this must be done 
seriously, since the revenue from digital media is far greater than from print media. This is the reason of why digital platforms have become the main business of Pikiran Rakyat.

\section{CONCLUSION}

Pikiran Rakyat carries out media convergence strategy by using three dimensions of media convergence; namely technological convergence, multimedia content, and ownership. The dimension of technological convergence conducted is to create a website pikiran- rakyat.com, create new innovations such as an Android-based application called MyPikirRakyat, while other recent innovations are PRTV platform that can be accessed via You Tube. Another dimension is multimedia content, this dimension is utilized very well by Pikiran Rakyat to get some content, it works closely with SMEs, youth clubs, vloggers, and local bloggers as well. The management of print and digital media content is certainly very different. Print media has a more relaxed working time, while digital media can be skipped or might be random, moreover multiple jobs might be done in one time.

Pikiran Rakyat is experiencing obstacles such as human resources who find themselves difficult to adapt the current technological developments. In addition, the technology in Pikiran Rakyat has been existed since 2000s. The direct impact experienced by the editorial staff is changing the mindset of employees, and employees working methods. Pikiran Rakyat did some evaluation in carrying out the process of media convergence such as to support the existing employees to be able to adapt to current technological developments. In addition, Pikiran Rakyat started to sort unproductive - productive employees. As well as to open a recruitment to find much younger and more productive human resources

\section{REFERENCE}

Chao-Chen, L. (2013). Convergence of new and old media: New media representation in traditional news. Chinese Journal of Communication, 6(2), 183-201. https://doi.org/10.1080/17544750.2013.785667

Gumelar, R. G. (2011). KONVERGENSI MEDIA ONLINE. Jurnal Komunikasi, Volume 2,(Konvergensi Media), 2013.

Haryanto, I. (2014). Jurnalisme Era Digital, Tantangan Industri Media Abad 21. Jakarta: PT. Kompas Media Nusantara.

Idi Subandy Ibrahim \& Akhmad, B. A. (2014). Komunikasi \& Komodifikasi, mengkaji media dan budaya dalam dinamika globalisasi (1st ed.). Jakarta: Yayasan Pustaka Obor Indonesia.

KPI. (2013). Kedaulatan Frekuensi, Regulasi penyiaran, Peran KPI, dan Konvergensi Media. Jakarta: Kompas Media Nusantara.

Prihatin, I. U. (2015). Media cetak Indonesia bertumbangan, ada indikasi sindrom menular. Merdeka.Com. Retrieved from https://www.merdeka.com/peristiwa/media-cetakindonesia- bertumbangan-ada-indikasi-sindrom-menular-bisnis-media-massaindonesia.html 